Article

\title{
Simultaneous Enhancement of Photocatalytic Bactericidal Activity and Strength Properties of Acrylonitrile-Butadiene-Styrene Plastic Via a Facile Preparation with Silane/ $/ \mathrm{TiO}_{2}$
}

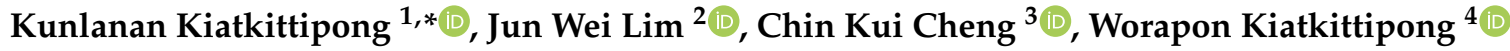 \\ and Suttichai Assabumrungrat ${ }^{5}$ \\ 1 Department of Chemical Engineering, Faculty of Engineering, King Mongkut's Institute of Technology \\ Ladkrabang, Bangkok 10520, Thailand \\ 2 Department of Fundamental and Applied Sciences, HICoE-Centre for Biofuel and Biochemical Research, \\ Institute of Self-Sustainable Building, Universiti Teknologi PETRONAS, Seri Iskandar 32610, Malaysia \\ 3 Faculty of Chemical and Natural Resources Engineering, Universiti Malaysia Pahang, \\ Pahang 26300, Malaysia \\ 4 Department of Chemical Engineering, Faculty of Engineering and Industrial Technology, Silpakorn \\ University, Nakhon Pathom 73000, Thailand \\ 5 Center of Excellence in Catalysis and Catalytic Reaction Engineering, Department of Chemical Engineering, \\ Faculty of Engineering, Chulalongkorn University, Bangkok 10330, Thailand \\ * Correspondence: kunlanan.kia@kmitl.ac.th; Tel.: +66-2329-8300
}

Received: 20 March 2020; Accepted: 11 April 2020; Published: 16 April 2020

\begin{abstract}
This work aims to enhance the photocatalytic antibacterial performance of plastics according to the JIS Z 2801:2010 standard, and to determine their mechanical properties by studying: (i) the influence of calcination on titanium dioxide $\left(\mathrm{TiO}_{2}\right)$; (ii) modification with different $\mathrm{TiO}_{2}$ concentrations, and; (iii) the effect of silane as a coupling agent. Acrylonitrile-butadiene-styrene plastics (ABS) and Escherichia coli (E. coli) were chosen as the model plastic and bacteria, respectively. The $500{ }^{\circ} \mathrm{C}$ calcined $\mathrm{TiO}_{2}$ successfully provided the best photoantibacterial activity, with an approximately $62 \%$ decrease of E. coli colony counts following $30 \mathrm{~min}$ of exposure. Heat treatment improved the crystallinity of anatase $\mathrm{TiO}_{2}$, resulting in low electron-hole recombination, while effectively adsorbing reactants on the surface. ABS with $500{ }^{\circ} \mathrm{C}$-calcined $\mathrm{TiO}_{2}$ at the concentration of $1 \mathrm{wt} \%$ gave rise to the highest performance due to the improved distribution of $\mathrm{TiO}_{2}$. At this point, blending silane coupling agent could further improve the efficacy of photoantibacterial activity up to $75 \%$ due to greater interactions with the polymer matrix. Moreover, it could promote a 1.6-fold increase of yield strength via increased adherent bonding between $\mathrm{TiO}_{2}$ and the ABS matrix. Excellent photocatalytic and material stability can be achieved, with constant photocatalytic efficiency remaining for up to five reuse cycles without loss in the yield strength.
\end{abstract}

Keywords: titania photocatalyst disinfection; photocatalytic degradation; aptes treatment; photocatalytic inactivation; photokilling

\section{Introduction}

Thermoplastic polymers are widely used for appliances such as sanitary ware, medical appliances, furniture and children's toys due to their favorable properties, such as excellent impact resistance, good machinability and excellent aesthetic qualities [1]. Durable plastics with a useful life of three years or more, such as Acrylonitrile-Butadiene-Styrene (ABS) plastics, could be potentially colonized by myriad microorganisms. Therefore, one of the biggest problems these plastics pose is microorganism 
contamination, including viruses, fungi and bacteria, which are harmful to the environment, hazardous to humans, and are difficult to disinfect. The generated reactive oxygen species (ROS) play a crucial role in bacterial disinfection. ROS can be generated by light irradiation or, more recently, by harnessing the power of microwaves using a conventional microwave oven $[2,3]$.

Photocatalysis have attracted considerable attention in solving bacterial contamination as a clean, energy-efficient, low-cost and environmentally friendly technology. Photocatalytic bacterial inactivation relies upon the generation of highly reactive short-lived hydroxyl radicals and reactive oxygen that efficiently damage the cell membranes of microorganisms. $\mathrm{TiO}_{2}$ is widely used for photocatalytic applications due to its high stability, low cost and non-toxicity [4,5]. For example, Ti-O nanostructures synthesized from $\mathrm{TiO}_{2}$ in alkaline hydrothermal conditions have enhance photocatalytic reaction rates and sedimentability [6]. Lee and Chang reviewed composite photocatalysts widely used for degradation of hazardous chemicals, antibacterial, and photocatalytic hydrogen production [7]. Polymeric membranes with $\mathrm{TiO}_{2}$ showed excellent degradation of pollutants in water due to active sites of $\mathrm{TiO}_{2}$ available for interacting with photons [8]. Moreover, in-situ-formed granular $\mathrm{TiO}_{2}$ on polyvinylidene fluoride (PVDF) fiber with graphitic carbon nitride exhibited excellent self-cleaning properties [9].

Coating $\mathrm{TiO}_{2}$ on polymers such as polypropylene [10,11], polyethylene terephthalate [12], polycarbonate [13], and polystyrene [14] has been proposed to reduce the abundance of Escherichia coli (E. coli) and other harmful microrganisms. The properties of $\mathrm{TiO}_{2}$ such as crystallinity, surface defects, and particle size may affect its photocatalytic activities. However, potential flaking-off of $\mathrm{TiO}_{2}$ is an issue when the polymer is used many times. This may increase the risk to human health and result in environmental hazards. Apart from the effect on microorganisms, awareness of the mechanical properties of thermoplastic polymers is another concern. Many studies have reported that the filler adhesion and dispersion on the matrix of polymers were the main factors [15].

There is a body of literature on the effects of $\mathrm{TiO}_{2}$ on physical and chemical characteristics of ABS composites. Adding commercially surface-treated $\mathrm{TiO}_{2}$ pigment to ABS shows some optical benefits; i.e., doing so can impart opacity and whiten the ABS polymer as indicated by an increasing whiteness index and decreasing yellowness index. Impact strength of $\mathrm{TiO}_{2}$-pigmented $\mathrm{ABS}$ improved with a small loading of $\mathrm{TiO}_{2}$ pigment [16]. The friction and wear properties of $\mathrm{TiO}_{2}-\mathrm{ABS}$ were investigated by varying the $\mathrm{TiO}_{2}$ content, normal load, and sliding speed. With optimization of these parameters, the friction and wear properties of $\mathrm{TiO}_{2}-\mathrm{ABS}$ could be improved [17]. Recently, $\mathrm{TiO}_{2}-\mathrm{ABS}$ nanocomposite filaments have been produced and applied in $3 \mathrm{D}$ printing. $\mathrm{TiO}_{2}-\mathrm{ABS}$ with 5 and 10 wt $\%$ loading possess higher breaking point stress thresholds than those printed from the pure ABS polymer. A $10 \% \mathrm{TiO}_{2}$-ABS preparation exhibited a marked photocatalytic activity leading to dye degradation, as observed by decreasing fluorescence emission spectra of rhodamine 6G by approx. $22 \%$ over $4 \mathrm{~h}$ of light exposure [18].

Although many studies have demonstrated the development of thermoplastic polymers in terms of their mechanical properties or in relation to microorganism suppression, there has been limited assessment of the antibacterial role of $\mathrm{TiO}_{2}$, and its effects on the strength of plastics. In particular, there is no previous study available on ABS plastic - a material that provides effective and quality products for various applications. The most relevant literature is our preliminary study of $\mathrm{TiO}_{2} / \mathrm{ABS}$ on photoantibacterial activity, without functionality or interfacial affinity modification, which resulted in unimpressive photoactivity [19]. Moreover, the impact of calcination and fillers on $\mathrm{TiO}_{2}$ properties, and its potential photoantibacterial effect, have not been investigated of late. This study focuses on improving photoantibacterial performance following the standard JIS Z 2801, which covers the ability of plastic surfaces to inhibit the growth of microorganisms. We also investigate strength properties (per standard ASTM D639 Type I) of ABS plastic with modified $\mathrm{TiO}_{2}$. The role of calcination temperature, concentration and silane-coupling agent is also assessed. 


\section{Materials and Methods}

\subsection{Reagents}

$\mathrm{TiO}_{2}$ (anatase 100\%), acrylonitrile-butadiene-styrene (ABS Resin, PA-717C Grade), 3-aminopropyltriethoxysilane (APTES) (Sigma-Aldrich, St. Louis, MI, USA), stock phosphate buffer solution (PBS) (Sigma-Aldrich), plate count agar (PCA), tryptic soy broth (TSB), peptone (J.T.Baker) were used.

\subsection{Calcination of $\mathrm{TiO}_{2}$ Powder}

Anatase $\mathrm{TiO}_{2}$ particles were preheated in an oven at $90^{\circ} \mathrm{C}$ for $2 \mathrm{~h}$, and then calcined at temperatures of 300,500 and $800{ }^{\circ} \mathrm{C}$ for $2 \mathrm{~h}$ with a ramping rate of $5{ }^{\circ} \mathrm{C} \mathrm{min}^{-1}$.

\subsection{Surface Modification of $\mathrm{TiO}_{2}$ with Silane}

A $0.5 \mathrm{~g}$ mass of calcined $\mathrm{TiO}_{2}$ was dispersed in $50 \mathrm{~cm}^{3}$ of $2.5 \% v / v$ ethanol. Then, $0.15 \mathrm{~g}$ of the silane-coupling agents (APTES) at standard conditions were added in the dispersion, and stirred for $45 \mathrm{~min}$. The resulting slurry was centrifuged and dried in an oven for $24 \mathrm{~h}$ at $80{ }^{\circ} \mathrm{C}$

\subsection{Preparation of $\mathrm{TiO}_{2} / \mathrm{ABS}$ Compositions}

Prior to blending polymers, ABS plastic was dried in an oven at $90{ }^{\circ} \mathrm{C}$ for $2 \mathrm{~h}$ to remove moisture. The $\mathrm{TiO}_{2}$ or calcined $\mathrm{TiO}_{2}$ particles (concentration of $0.5,1$ and 2 wt $\%$ ) or calcined $\mathrm{TiO}_{2}$ treated with silane, and ABS plastic were loaded into a twin-screw extruder, and then mixed well in an internal mixer at $250{ }^{\circ} \mathrm{C}$ with speed round mixing at $60 \mathrm{rpm}$ for $6 \mathrm{~min}$. The melting material was put in the mold $\left(5 \times 5 \mathrm{~cm}^{2}\right)$ by using a compression molding at a temperature of $250{ }^{\circ} \mathrm{C}$ and pressure of $125 \mathrm{~kg} \mathrm{~cm}^{-2}$ for $5 \mathrm{~min}$, and rapidly cooled for $5 \mathrm{~min}$. The resulting $\mathrm{TiO}_{2} / \mathrm{ABS}$ compositions were air-cooled at room temperature before being tested.

\subsection{E. coli Bacteria Preparation and Photoantibacterial Activity}

Photoantibacterial activity and efficacy assessments followed the standard JIS Z 2801 (The test for antibacterial activity and efficacy on surfaces of antibacterial products). A colony of E. coli bacteria was transferred into TSB solution, and then incubated at $32 \pm 0.5^{\circ} \mathrm{C}$ for $24 \mathrm{~h}$. The bacterial suspensions were diluted into $2.5 \times 10^{8} \mathrm{cfu} \mathrm{cm}^{-3}$, dropped on $\mathrm{TiO}_{2} / \mathrm{ABS}$ workpieces, and covered with a polyethylene (PE) film size $4 \times 4 \mathrm{~cm}^{2}$. The sample was illuminated by UVC light $(15 \mathrm{~W})$ for $30 \mathrm{~min}$. The bacterial population was determined by plated serial dilution, and plates were incubated at $32 \pm 0.5^{\circ} \mathrm{C}$ for $24 \mathrm{~h}$. All photoantibacterial activity experiments were performed with three replicates (independent experiments), and the data were represented as the average mean \pm SD (error bar).

\subsection{Sample Characterization}

Crystal and structural characteristics of the products and crystallinity were investigated using powder X-ray diffraction (XRD) system with monochromatized $C u_{k \alpha}$ radiation $(\lambda=1.5406 \AA)$. Full width at half maximum (FWHM) derived from XRD patterns at $2 \theta=25^{\circ}$ indicated the degree of crystallinity. Sample morphology was investigated by a scanning electron microscope, and the surface area and pore size distribution were determined by $\mathrm{N}_{2}$ adsorption.

\subsection{Mechanical Tensile Strength}

The workpieces were tested using a universal testing machine according to the guidelines set in ASTM D639 Type I (Standard Test Method for Tensile Properties of Plastics). All experiments were performed with three replicates, and the data were represented as the average mean \pm SD (error bar). 


\section{Results and Discussion}

\subsection{Effect of Calcination Temperatures on $\mathrm{TiO}_{2}$}

The crystal structure of $\mathrm{TiO}_{2}$ was investigated by XRD analysis as shown in Figure 1 and corresponding crystallite size was calculated by using the Debye-Scherrer formula. The XRD pattern demonstrated that $\mathrm{TiO}_{2}$ structures were influenced by calcination temperatures. The initial $\mathrm{TiO}_{2}$ results included peaks at $2 \theta=25.4^{\circ}, 37.8^{\circ}, 48^{\circ}, 54.5^{\circ}$ and $62.8^{\circ}$, corresponding to the anatase phase of $\mathrm{TiO}_{2}$ with the FWHM value of 0.5 and particle size of $6.12 \mathrm{~nm}$. No peaks caused by impurities were observed. $\mathrm{TiO}_{2}$ calcined at $300{ }^{\circ} \mathrm{C}$ showed that the intensity of crystallinity of anatase increased, with a lower FWHM value of 0.41 and particle size of $7.08 \mathrm{~nm}$. Further increases in temperature to 500 and $800{ }^{\circ} \mathrm{C}$ increased crystallinity of anatase, as shown by recorded FWHM values of 0.27 and 0.08 , respectively. Therefore, crystalline structure was slightly developed by increasing the calcination temperatures. The particle sizes of 500 and $800{ }^{\circ} \mathrm{C}$ calcined $\mathrm{TiO}_{2}$ increased slightly to 7.13 and $7.15 \mathrm{~nm}$, respectively.

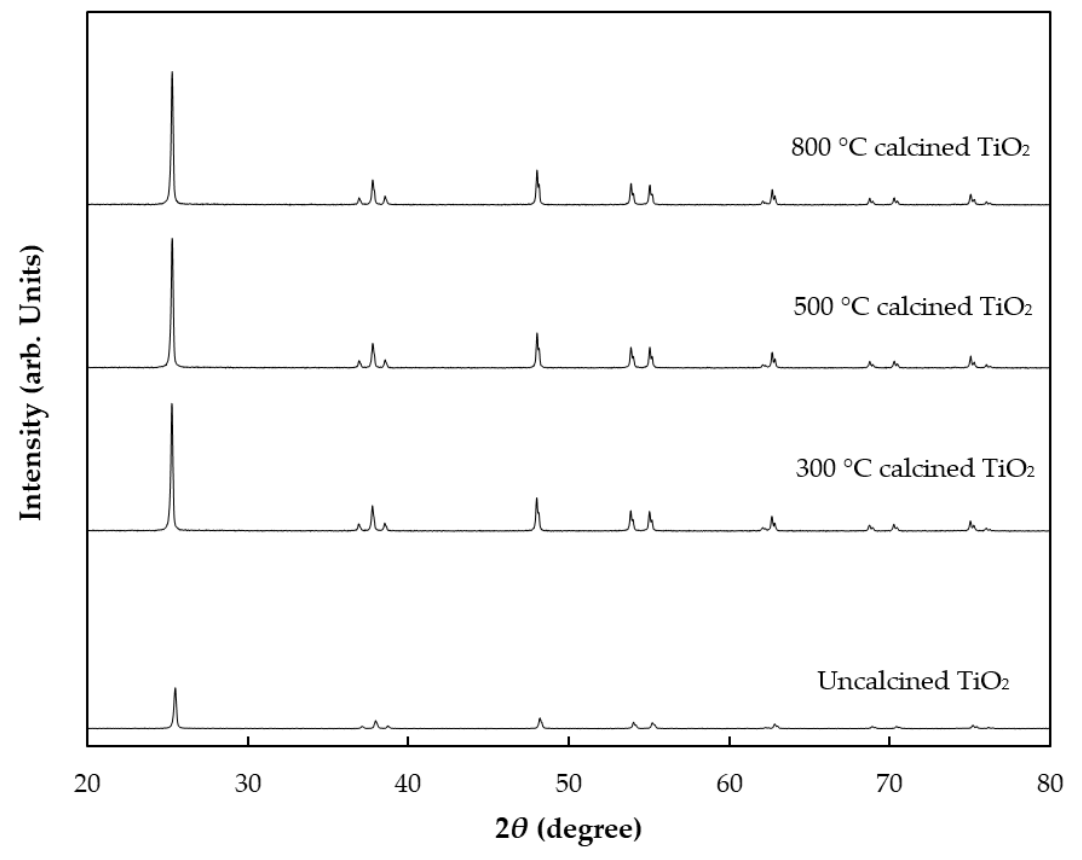

Figure 1. XRD patterns of uncalcined $\mathrm{TiO}_{2}$ (bottom) and $\mathrm{TiO}_{2}$ calcined at different temperatures.

The initial surface area of $\mathrm{TiO}_{2}$ was $10 \mathrm{~m}^{2} \mathrm{~g}^{-1}$. At $300{ }^{\circ} \mathrm{C}$, the specific surface area was reduced to $9 \mathrm{~m}^{2} \mathrm{~g}^{-1}$. A continuous decrease in surface area with the rise of calcination temperature was observed in $\mathrm{TiO}_{2}$ calcined at 500 and $800{ }^{\circ} \mathrm{C}$, with respective surface areas of 7 and $4 \mathrm{~m}^{2} \mathrm{~g}^{-1}$. The influence of calcination temperature on morphology was investigated by SEM imaging as presented in Figure 2. Initially, the $\mathrm{TiO}_{2}$ particles had a diameter of approximately $200 \mathrm{~nm}$ as shown in Figure 2a. When mixing $\mathrm{TiO}_{2}$ particles with ABS plastic, the particles appeared to be embedded in the ABS plastic, resulting in the rough surface, as observed in Figure $2 \mathrm{~b}$. Calcining at $300{ }^{\circ} \mathrm{C}$ led to structural aggregation of $\mathrm{TiO}_{2}$ particles (Figure 2c), whereby the surface of ABS plastic contained assemblies of particles in some areas (Figure 2d). At $500{ }^{\circ} \mathrm{C}$, it was also observed that a continuous aggregation in $\mathrm{TiO}_{2}$ particles occurred (Figure 2e) and these were visibly assembled on the ABS surface (Figure 2f). When the temperature was increased to $800{ }^{\circ} \mathrm{C}$, the $\mathrm{TiO}_{2}$ particles became obviously aggregating as seen in Figure 2g. Calcination of $\mathrm{TiO}_{2}$ results in partial or total collapse of the structure, decreasing of surface area, and the appearance of particle agglomerations. This resulted in poorly dispersed distribution of $\mathrm{TiO}_{2}$ particles on ABS plastic as shown in Figure 2h. The higher degree of agglomeration was ordered as follows: $800{ }^{\circ} \mathrm{C}-\mathrm{TiO}_{2} / \mathrm{ABS}>500{ }^{\circ} \mathrm{C}-\mathrm{TiO}_{2} / \mathrm{ABS}>300{ }^{\circ} \mathrm{C}-\mathrm{TiO}_{2} / \mathrm{ABS}>$ uncalcined- $\mathrm{TiO}_{2} / \mathrm{ABS}$, and could be affirmed by orderly lowering yield strength, as shown in the next section. 

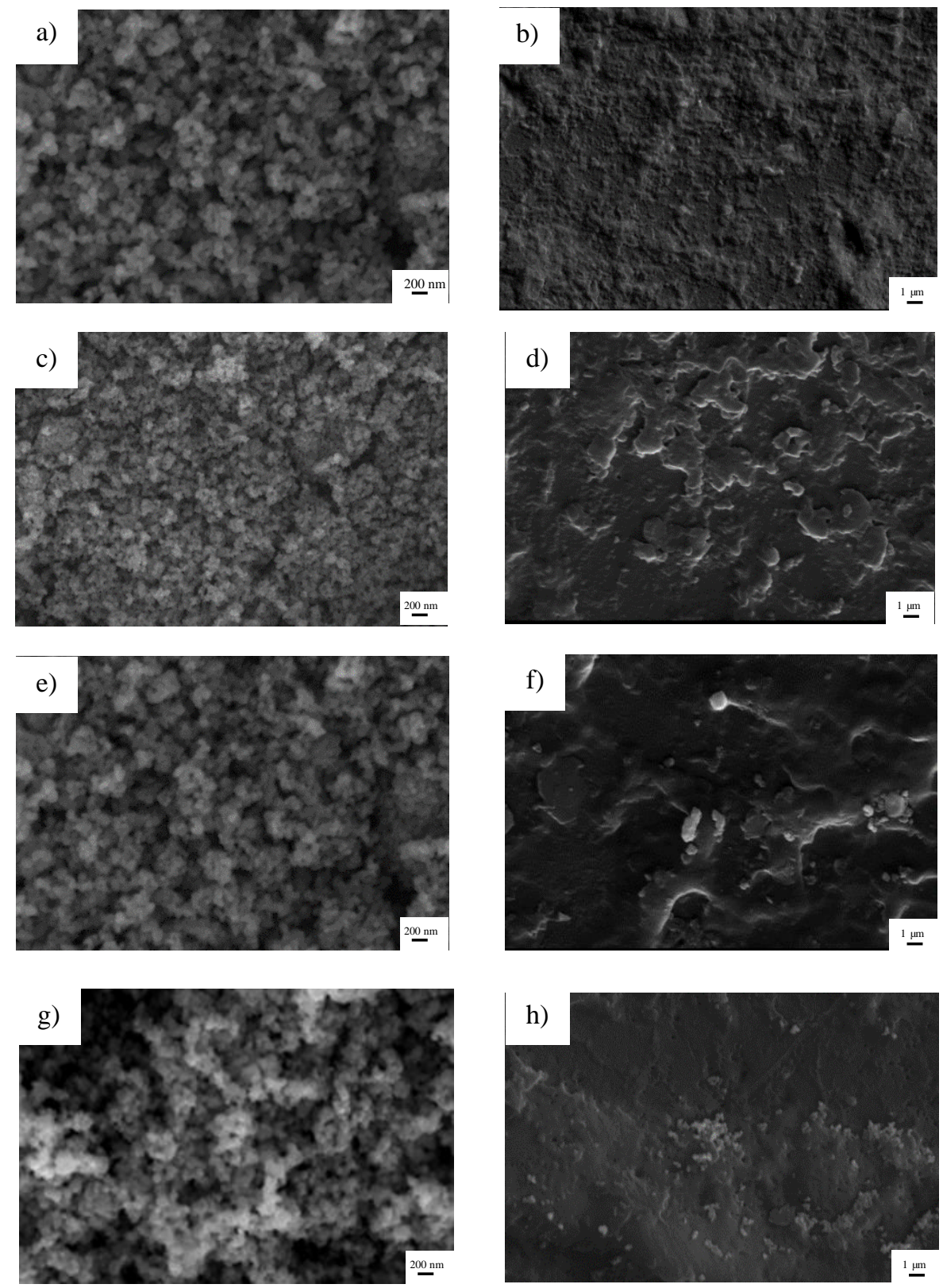

Figure 2. SEM images of (a) $\mathrm{TiO}_{2}$, (b) $\mathrm{TiO}_{2} / \mathrm{ABS}$, (c) $300{ }^{\circ} \mathrm{C}$ calcined $\mathrm{TiO}_{2}$, (d) $300{ }^{\circ} \mathrm{C}$ calcined $\mathrm{TiO}_{2} / \mathrm{ABS}$, (e) $500{ }^{\circ} \mathrm{C}$ calcined $\mathrm{TiO}_{2}$, (f) $500{ }^{\circ} \mathrm{C}$ calcined $\mathrm{TiO}_{2} / \mathrm{ABS}$, (g) $800{ }^{\circ} \mathrm{C}$ calcined $\mathrm{TiO}_{2}$, (h) $800{ }^{\circ} \mathrm{C}$ calcined $\mathrm{TiO}_{2} / \mathrm{ABS}$.

\subsection{Effect of $\mathrm{TiO}_{2}$ with and without Calcination on Photoantibacterial Activity and Yield Strength of ABS}

The influence of $\mathrm{TiO}_{2}$ and calcined $\mathrm{TiO}_{2}$ mixed with $\mathrm{ABS}$ on photoantibacterial Escherichia coli (E. coli) as assessed by the JIS Z 2801: 2010 standard test are illustrated in Figure 3. Photoantibacterial effectiveness for E. coli was presented in the form of bacterial survival. The result obtained for pure ABS under UV illumination for 30 min showed little antibacterial activity, while the E. coli survival of $60 \pm 2.8 \%$ was observed in $\mathrm{ABS}$ with $\mathrm{TiO}_{2}$, highlighting the dominant impact of $\mathrm{TiO}_{2}$ in influencing photocatalytic activity. Figure 4 illustrates the mechanism of photocatalytic antibacterial action proposed, in which the $\mathrm{OH}$ radicals and reactive oxygen species (ROS) generated by $\mathrm{TiO}_{2}$ would damage the cell membrane, resulting in the leakage of bacterial cytoplasm, leading to cell death [20-22]. Moreover, the calcined $\mathrm{TiO}_{2}$ mixed with $\mathrm{ABS}$ provided a greater reduction of $E$. coli compared to uncalcined $\mathrm{TiO}_{2} / \mathrm{ABS}$. Calcining $\mathrm{TiO}_{2}$ at $300{ }^{\circ} \mathrm{C}$ could decrease $E$. coli on $\mathrm{ABS}$ by $45 \pm 2.1 \%$ (remaining 
bacterial survival $55 \%$ ), further decreasing to $60 \pm 2.6 \%$ at $500^{\circ} \mathrm{C}$ (remaining bacterial survival $40 \%$ ), despite a decrease in surface area. The photocatalytic improvement could be plausibly explained by a higher degree of crystallinity as mentioned earlier. That is, the more-active crystal phase was improved and surface defects were reduced as documented by several studies [23-26]. However, when increasing calcination temperature up to $800^{\circ} \mathrm{C}$, the photoantibacterial performance decreased. This may derive from sintering and agglomeration effects during calcination at high temperature, as shown in SEM imagery (Figure 2).

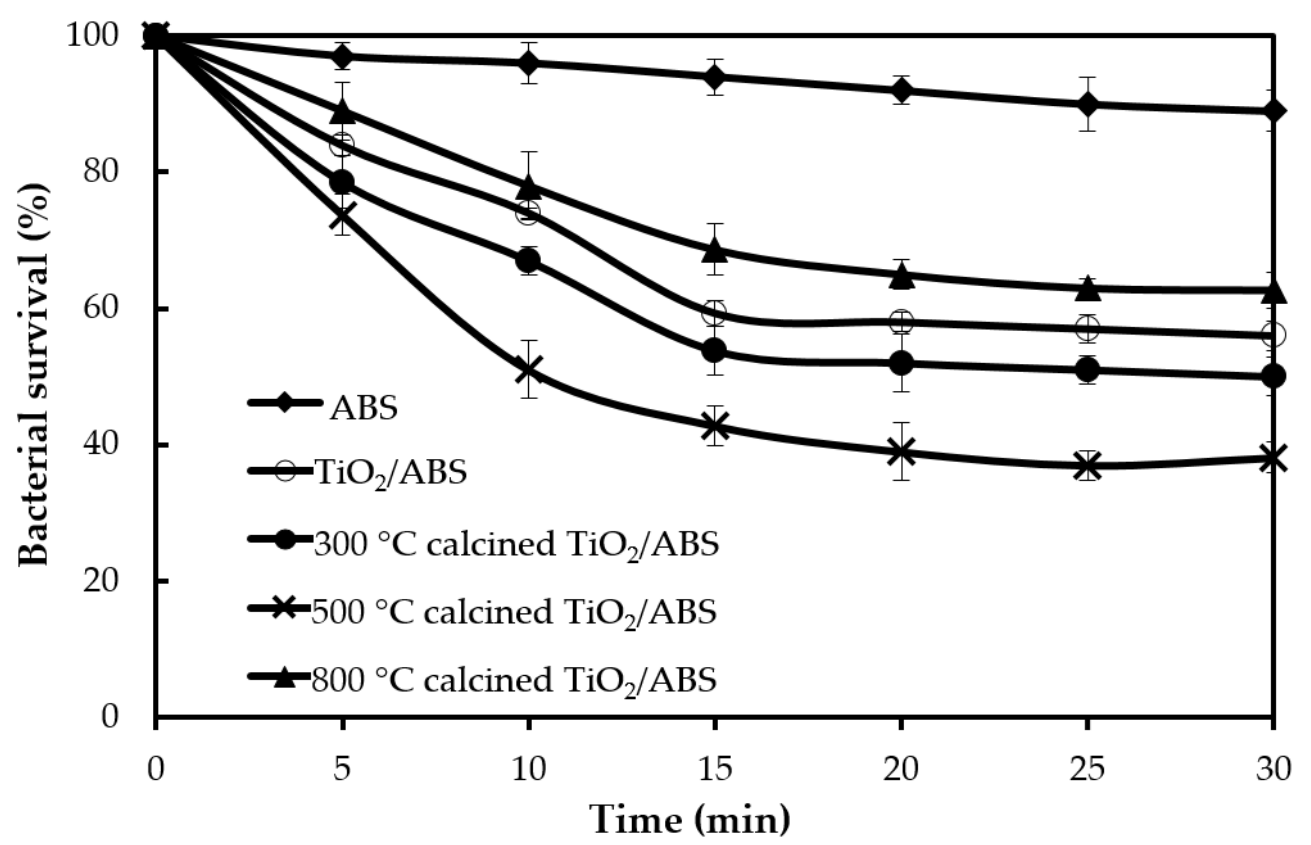

Figure 3. Bacterial survival following photocatalytic reaction of $\mathrm{ABS}, \mathrm{TiO}_{2} / \mathrm{ABS}$ and $300-800{ }^{\circ} \mathrm{C}$ calcined $\mathrm{TiO}_{2} / \mathrm{ABS}\left(\mathrm{TiO}_{2}\right.$ concentration of 1 wt \%).

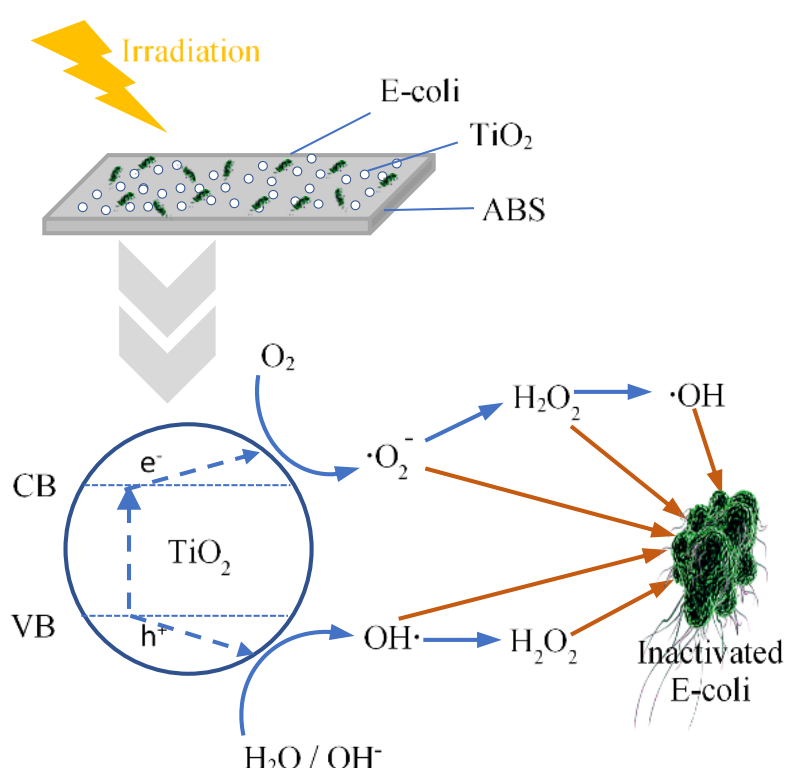

Figure 4. The mechanism underlying the photocatalytic antibacterial effect.

Figure 5 shows that the yield strength of plain ABS was $16.7 \pm 0.1 \mathrm{MPa}$, which was in the standard range of mechanical strength for this material. ABS containing $\mathrm{TiO}_{2}$ could further improve the yield strength of the workpiece. The enhancement of strength can be explained by $\mathrm{TiO}_{2}$ creating 
temporary crosslinks among the polymer chains during the deformation process. In particular, uncalcined $\mathrm{TiO}_{2} / \mathrm{ABS}$ showed the highest values of yield strength with a yield point of $17.2 \pm 0.2 \mathrm{MPa}$. A slight decrease of yield strength was observed when increasing calcination temperature of $\mathrm{TiO}_{2}$. The yield strengths of $300{ }^{\circ} \mathrm{C} \mathrm{TiO}_{2} / \mathrm{ABS}, 500{ }^{\circ} \mathrm{C} \mathrm{TiO} / \mathrm{ABS}$ and $800{ }^{\circ} \mathrm{C} \mathrm{TiO} /$ ABS were $17.1 \pm 0.3$, $17.0 \pm 0.3$ and $16.9 \pm 0.2 \mathrm{MPa}$, respectively. The decrease of yield strength may be attributed to increasing agglomeration and reduced surface area of $\mathrm{TiO}_{2}$ (e.g., a lower interfacial area for bonding to the ABS polymer) with increasing calcination temperature, as seen from SEM imagery (Figure 2), which contributed to formation of fewer crosslinks among the polymer chains.

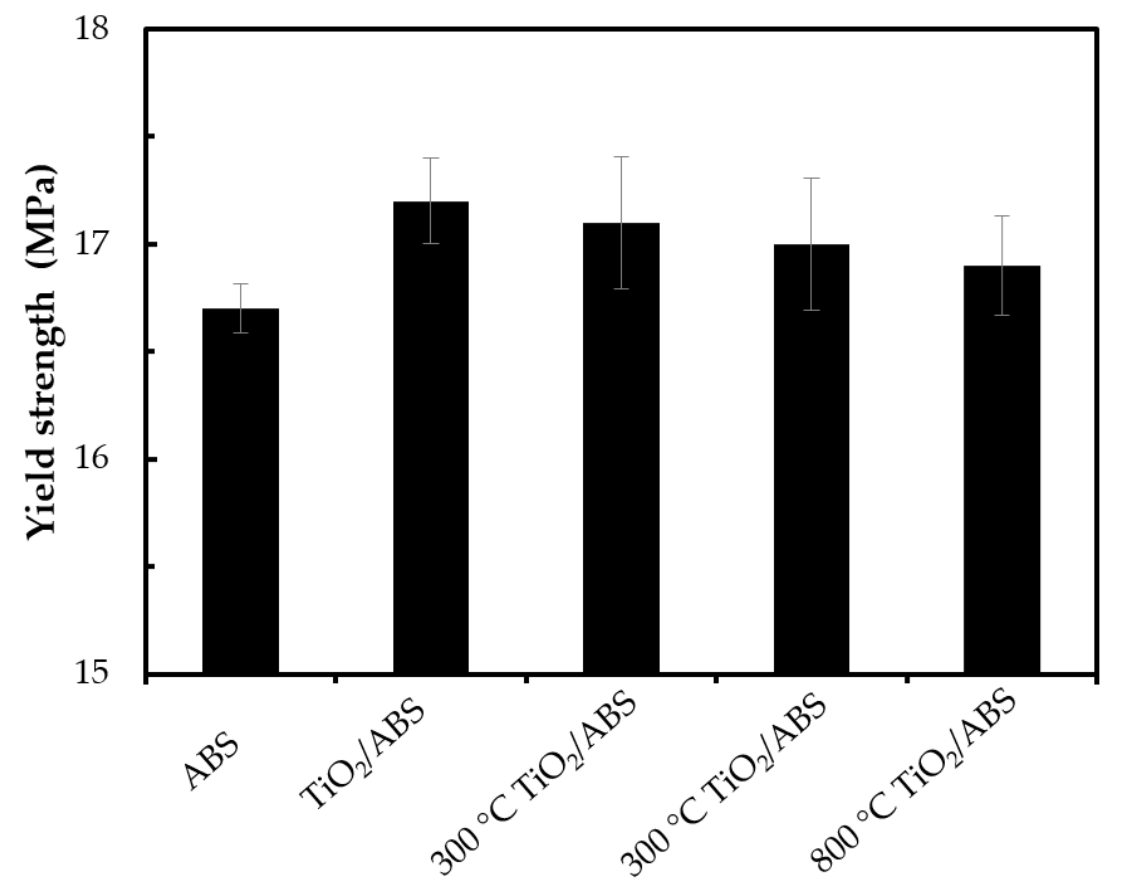

Figure 5. Yield strength of $\mathrm{ABS}, \mathrm{TiO}_{2} / \mathrm{ABS}$ and $300{ }^{\circ} \mathrm{C}-800{ }^{\circ} \mathrm{C}$-calcined $\mathrm{TiO}_{2} / \mathrm{ABS}\left(\mathrm{TiO}_{2}\right.$ concentration of $1 \mathrm{wt} \%)$.

\subsection{Effect of Concentration of Calcined $\mathrm{TiO}_{2}$ on Photoantibacterial Activity and Yield Strength of ABS}

The previous section demonstrates that optimum performance on photocatalytic performance occurred at $500{ }^{\circ} \mathrm{C}$ for calcined $\mathrm{TiO}_{2} / \mathrm{ABS}$. In this section, the influence of $500{ }^{\circ} \mathrm{C}$-calcined $\mathrm{TiO}_{2}$ concentration in ABS on photocatalytic performance was considered. From the $40 \%$ bacterial survival by $1 \mathrm{wt} \%$ calcined $\mathrm{TiO}_{2} / \mathrm{ABS}$, changing of $\mathrm{TiO}_{2}$ concentration had been considered, as shown in Figure 6. The reduced concentration of $\mathrm{TiO}_{2}$ resulted in the increase of bacterial survival by $50 \pm 2.2 \%$. This indicated that the smaller amount of $\mathrm{TiO}_{2}$ was not enough to produce $\mathrm{OH}$ radicals and reactive oxygen species (ROS) to inactivate the bacteria. However, by increasing the concentration to $2 \mathrm{wt} \%$, the bacterial survival increased to $70 \pm 2.5 \%$. This showed that presence of large amounts of $\mathrm{TiO}_{2}$ did not always lead to the high photocatalytic activity, but may in fact suppress the activity due to their aggregation.

Figure 7 shows that yield strength decreased with increasing of $\mathrm{TiO}_{2}$ loading. A $0.5 \mathrm{w}$ t $\% \mathrm{TiO}_{2} / \mathrm{ABS}$ had the highest yield strength of $18.0 \pm 0.3 \mathrm{MPa}$. This was to be expected given the higher $\mathrm{TiO}_{2}$ inducing the effective matrix reduction. In other words, higher $\mathrm{TiO}_{2}$ loading ( 1 and $\left.2 \mathrm{wt} \%\right)$ increase "particle-to-particle" interactions rather than "particle-to polymer" interactions, thus lowering yield strength [27]. 


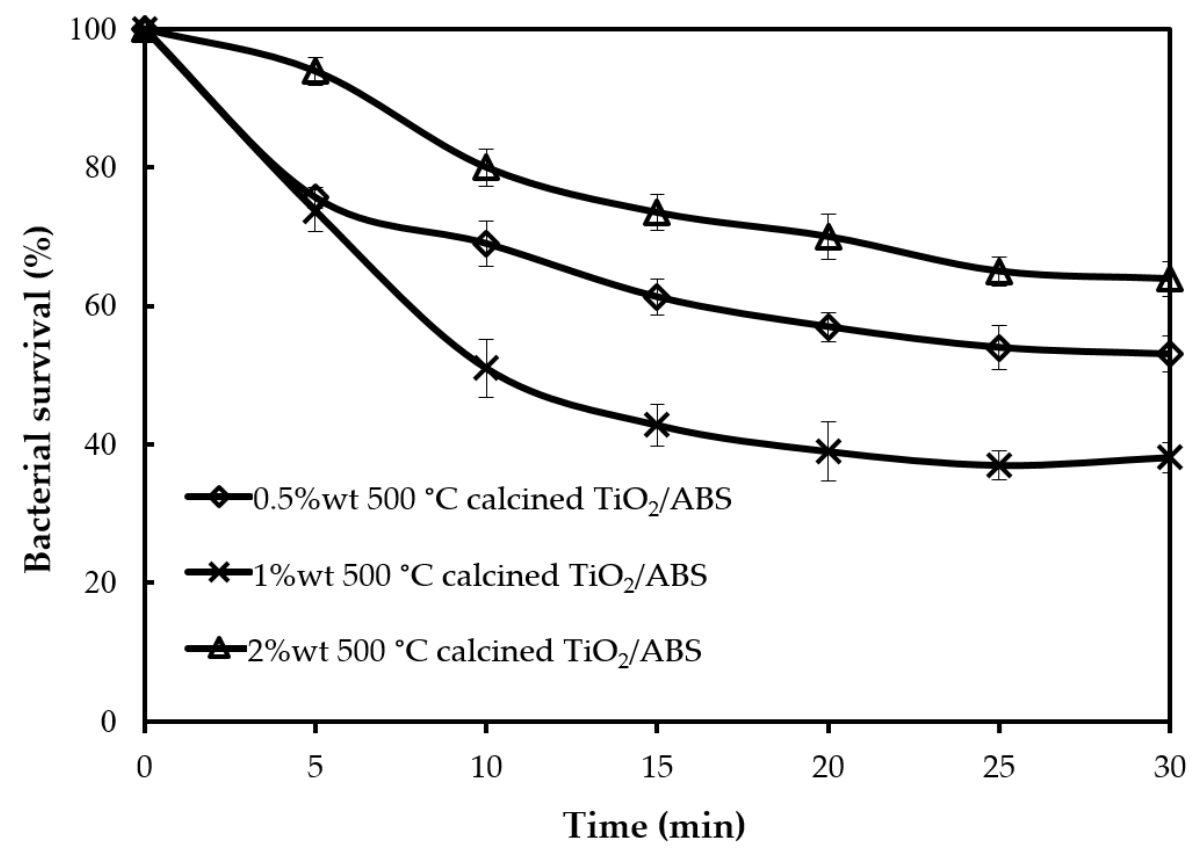

Figure 6. Bacterial survival by photocatalytic reaction of $\mathrm{ABS}$ with $500{ }^{\circ} \mathrm{C}$ calcined $\mathrm{TiO}_{2}$ at different concentrations.

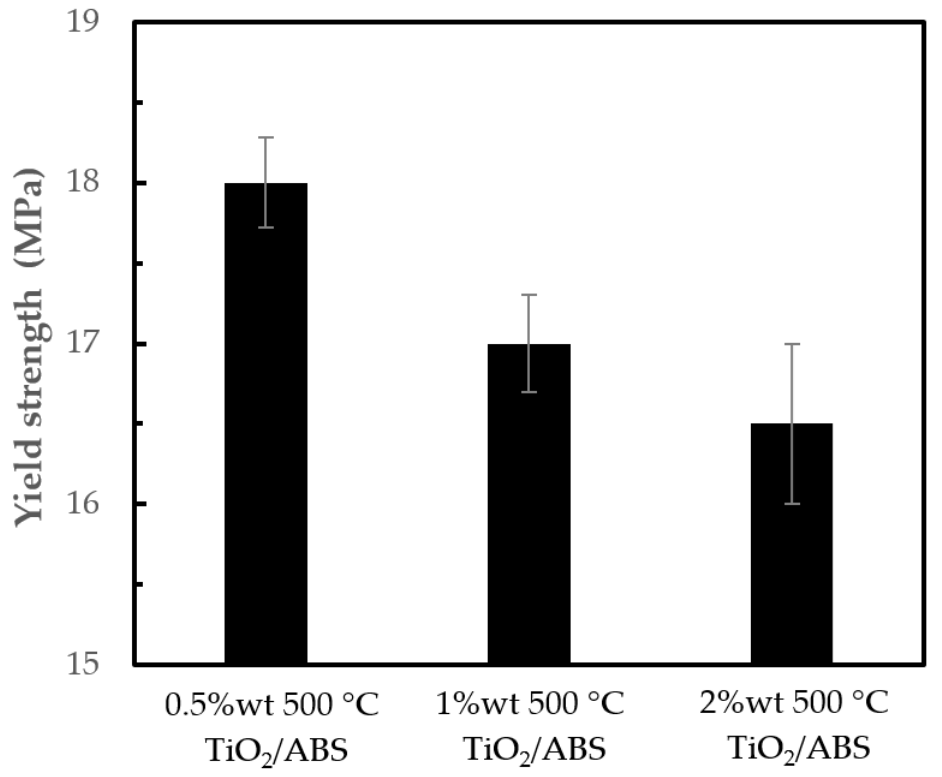

Figure 7. Yield strength of $\mathrm{ABS}$ with $500{ }^{\circ} \mathrm{C}$ calcined $\mathrm{TiO}_{2}$ at different concentrations.

\subsection{Effect of Silane on Photoantibacterial Activity and Yield Strength of ABS}

The influence of silane on $\mathrm{TiO}_{2} / \mathrm{ABS}$ was observed in the SEM images shown in Figure 8, in which the $500{ }^{\circ} \mathrm{C}$-calcined $\mathrm{TiO}_{2} / \mathrm{ABS}$ without silane possessed rough surfaces and smaller particles on the ABS surface, as illustrated in Figure 8a. After mixing silane, the morphology of blended polymer in Figure $8 b$ shows the presence of a smooth surface and better dispersion, rather than $\mathrm{TiO}_{2} / \mathrm{ABS}$. The difference was attributed to a greater interactions with the polymer matrix, which silane coupling agent showed the compatible behaviour of $\mathrm{ABS} / \mathrm{TiO}_{2}$ by creating more adherent bonding between $\mathrm{TiO}_{2}$ and ABS matrix, as similarly explained for the modified $\mathrm{SiO}_{2}$ with silane [28-30]. 

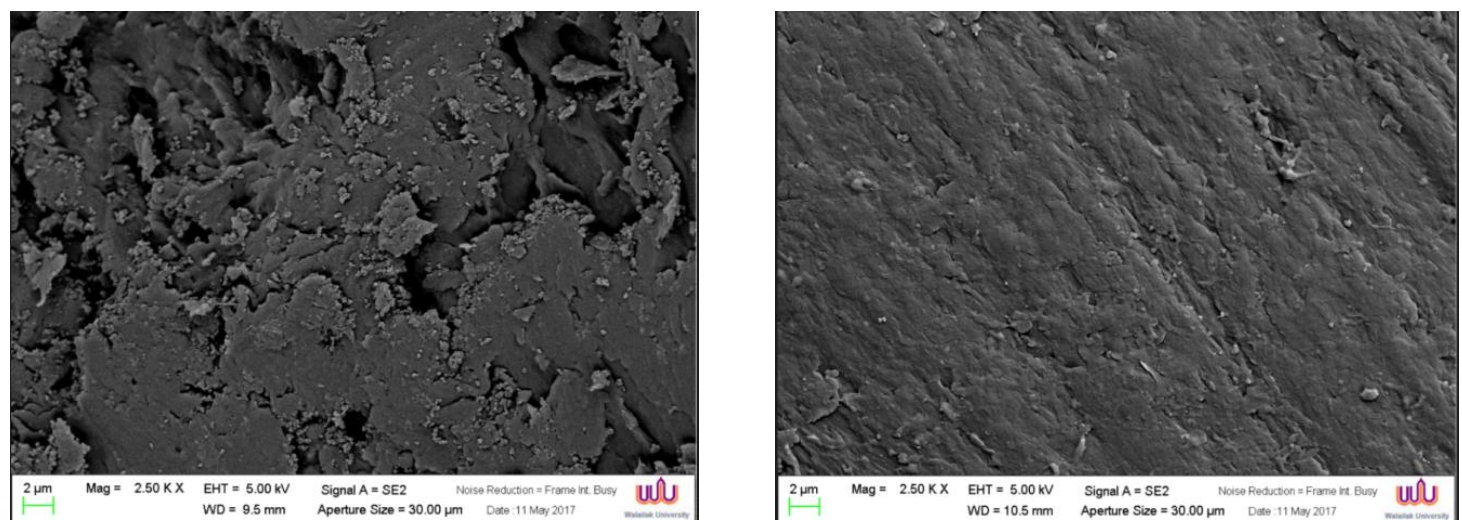

Figure 8. SEM of (a) $500{ }^{\circ} \mathrm{C}$ calcined $\mathrm{TiO}_{2} / \mathrm{ABS}$ and (b) $500{ }^{\circ} \mathrm{C}$ calcined $\mathrm{TiO}_{2} / \mathrm{ABS}$ with silane.

To investigate the effect of silane on photocatalytic activity, the ratio of $\mathrm{TiO}_{2}$ to silane during catalyst preparation was varied over the weight ratio of 1:0.2-1:0.5. The optimum photocatalytic activity occurred for samples at a ratio of $\mathrm{TiO}_{2}$ to silane of 1:0.3 as presented in Figure 9. Figure 9 reveals that $500{ }^{\circ} \mathrm{C}$-calcined $\mathrm{TiO}_{2} / \mathrm{ABS}$ with silane (called "silane- $\mathrm{TiO}_{2} / \mathrm{ABS}$ " for brevity) displays a better photobacterial activity compared with $500{ }^{\circ} \mathrm{C}$-calcined $\mathrm{TiO}_{2} / \mathrm{ABS}$ without silane. The silane-TiO $/ \mathrm{ABS}$ could reduce $75 \%$ of $E$. coli (remaining bacteria survival $25 \pm 2.6 \%$ ). The higher silane- $\mathrm{TiO}_{2} / \mathrm{ABS}$ photobacterial activity was attributed to the comparatively greater distribution of $\mathrm{TiO}_{2}$ on $\mathrm{ABS}$ which promoted good UV absorption; however this result did not agree with the findings of Pazokifard et al. [31], who reported that in a case of degradation of rhodamine, $\mathrm{TiO}_{2} \mathrm{P} 25$ nanoparticles showed a better activity than silane-treated particles due to the reduced surface area of $\mathrm{TiO}_{2}$ affecting poor photon absorption. The differences between the photocatalytic activity findings for bacteria and rhodamine likely originate from the operating conditions when blending the composite and the particle itself. The inset of Figure 9 shows that the yield strength of silane- $\mathrm{TiO}_{2} / \mathrm{ABS}$ was 1.6 times higher than $\mathrm{TiO}_{2} / \mathrm{ABS}$ without silane. The yield strength improvement was ascribed to better dispersion and adhesion of $\mathrm{TiO}_{2}$ in the ABS matrix, which arose from the silane coupling agent, enhancing interfacial bonding between the $\mathrm{TiO}_{2}$ and the matrix. We could highlight one key finding here, that the incorporation of silane results in improvement of $\mathrm{TiO}_{2}$ particls dispersion within the ABS polymeric matrix (shown as higher photocatalytic activity) and increasing possible interactions between $\mathrm{TiO}_{2}$ particles and the matrix (shown as higher yield strength).

\subsection{Reusability and Robustness}

The stability and reusability in terms of photocatalytic activity and the robustness of the composite material are crucial for practical applications. Therefore, the antibacterial experiments were repeated without any treatment on the specimen between the cycle runs. Constant photocatalytic efficiency was observed after five reuse cycles without loss in the yield strength of material, as shown in Figure 10. This suggests that blending calcined $\mathrm{TiO}_{2}$ into $\mathrm{ABS}$ prevented the loss of $\mathrm{TiO}_{2}$ photocatalyst particles from the surface, which is usually observed when coating $\mathrm{TiO}_{2}$ on the polymer surface. As expected, Ti content in the ABS plastic after the fifth run was identical to the as-prepared material (as determined by inductively coupled plasma atomic emission spectroscopy (ICP-OES). This robust ABS material could minimize detachment and release of $\mathrm{TiO}_{2}$ leading to lessening of the possibly negative environmental fates, transport, transformation and toxicity. 


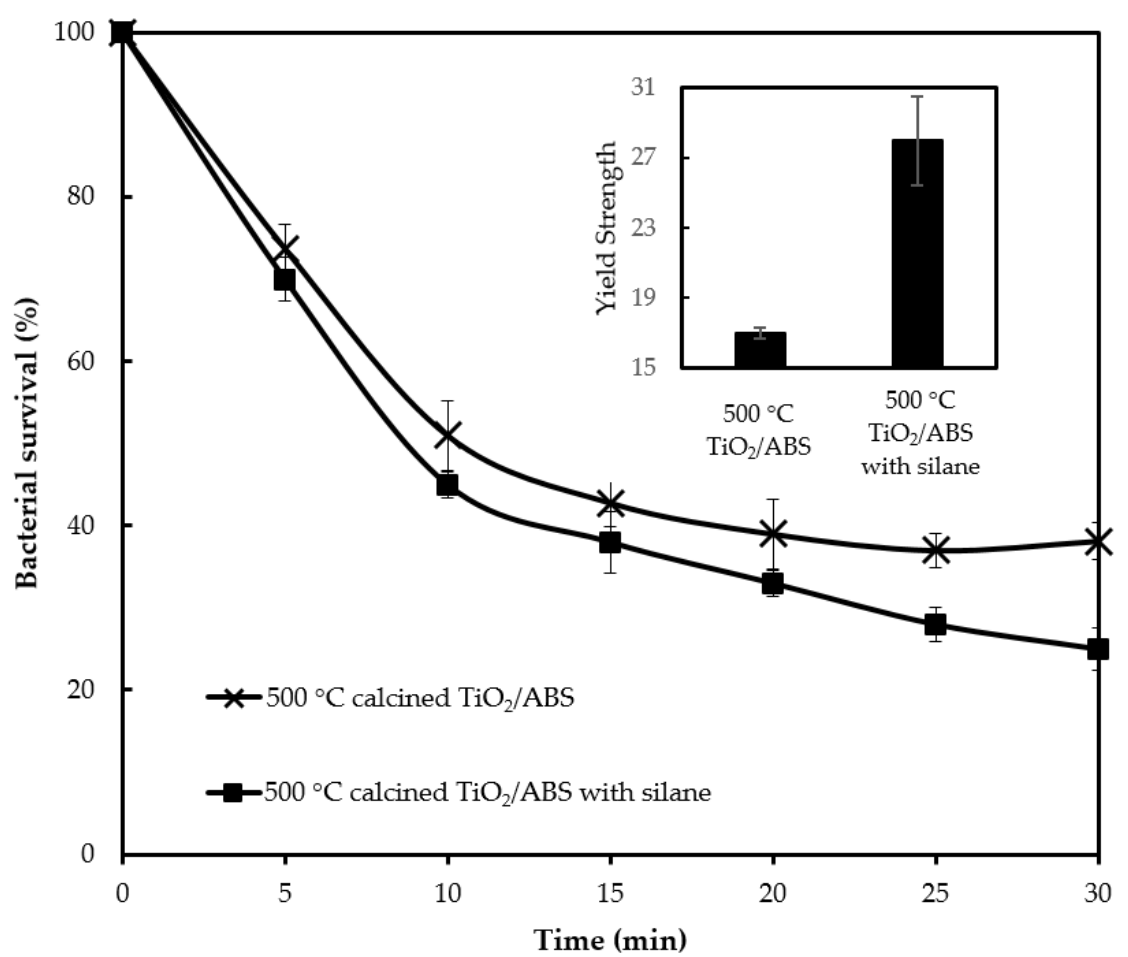

Figure 9. Bacterial survival by photocatalytic reaction of $\mathrm{ABS}$ with $500{ }^{\circ} \mathrm{C}$ calcined $\mathrm{TiO}_{2}(1 \mathrm{wt} \%$ loading $)$ with and without silane and corresponding their yield strength (inset).

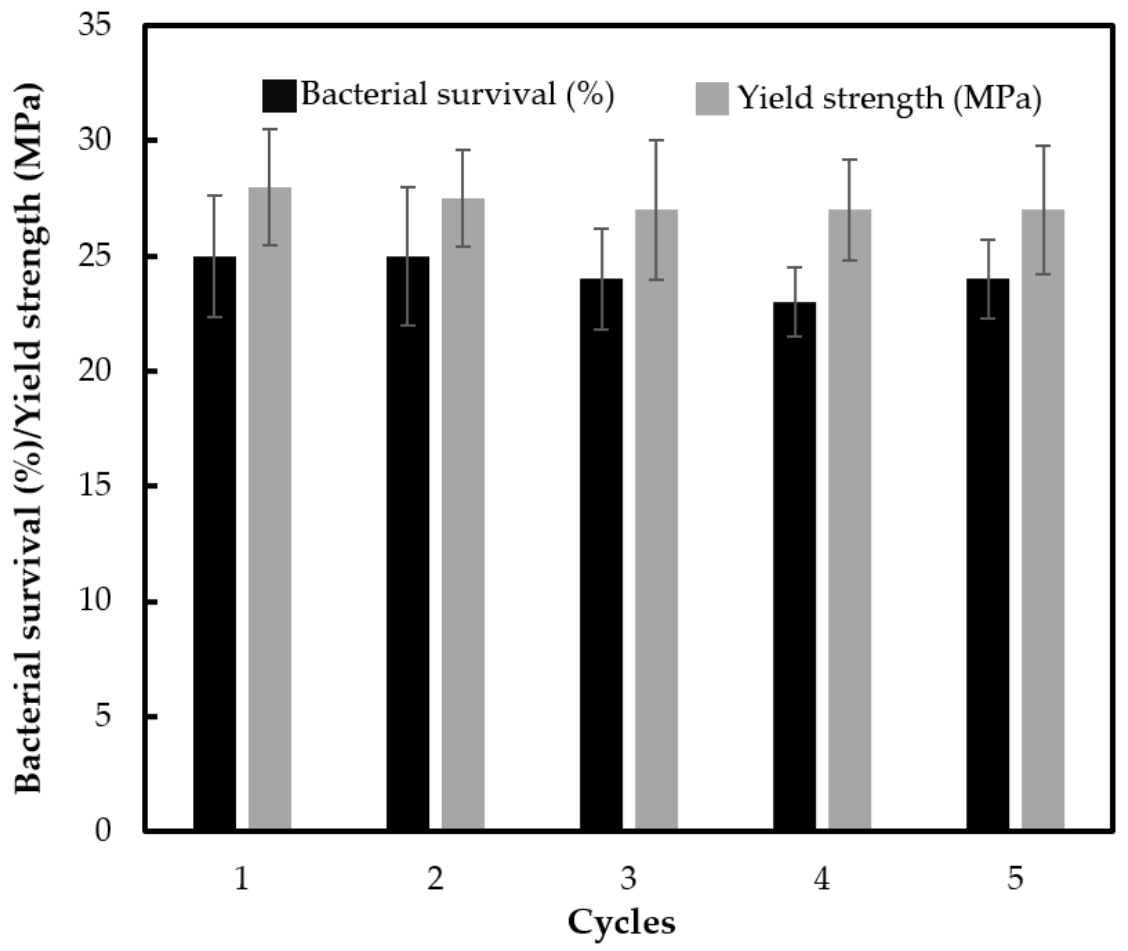

Figure 10. Reusability of $\mathrm{ABS}$ with $500{ }^{\circ} \mathrm{C}$ calcined $\mathrm{TiO}_{2}(1 \mathrm{wt} \%$ loading) with silane grafting up to the 5 th cycle in terms of bacterial survival by photocatalytic reaction, and the yield strength of the material (photo irradiation time of $30 \mathrm{~min}$ for each cycle).

\section{Conclusions}

Titanium dioxide $\left(\mathrm{TiO}_{2}\right)$ was found to influence antibacterial performance and yield strength enhancement when blended with acrylonitrile-butadiene-styrene plastics (ABS). The optimum 
photoantibacterial activity occurred for $\mathrm{ABS}$ in the $500{ }^{\circ} \mathrm{C}$-calcined $\mathrm{TiO}_{2}$ at a concentration of $1 \mathrm{wt} \%$. At this temperature and concentration, the high degree of crystallinity and optimal amount of $\mathrm{TiO}_{2}$, were sufficient to produce $\mathrm{OH}$ radicals and reactive oxygen species (ROS), resulting in damage to bacterial cell membranes. The photoantibacterial performance for $500{ }^{\circ} \mathrm{C}$ calcined $\mathrm{TiO}_{2}$ at $1 \mathrm{wt} \%$ in ABS was more efficient than plain ABS over $62 \%$. With optimal conditions, silane addition could further improve $\mathrm{TiO}_{2}$ dispersion on ABS. This resulted in a decrease of bacterial survival by $75 \%$. Moreover, the benefit of $\mathrm{TiO}_{2}$-embedded ABS plastic could improve yield strength than pure ABS. The yield strength of $\mathrm{TiO}_{2} / \mathrm{ABS}$ with silane was $67.7 \%$ higher than of pure ABS. The efficiency of $\mathrm{TiO}_{2} / \mathrm{ABS}$ with silane photocatalyst showed an excellent photocatalytic antibacterial stability after five reuses, without loss in the yield strength.

Author Contributions: Conceptualization, K.K.; investigation, K.K.; data curation, K.K.; writing一original draft preparation, K.K.; writing — review and editing, K.K., J.W.L., C.K.C, W.K. and S.A.; funding acquisition, K.K. All authors have read and agreed to the published version of the manuscript.

Funding: This research was funded by the by the Thailand Research Fund (TRF) and Office of the Higher Education Commission (Grant No. MRG6180262), and King Mongkut's Institute of Technology Ladkrabang, KMITL with the Grant No. CRT28/2561.

Acknowledgments: Financial support by the Thailand Research Fund (TRF) and Office of the Higher Education Commission (Grant No. MRG6180262) and King Mongkut's Institute of Technology Ladkrabang (Grant No. CRT28/2561) is gratefully acknowledged. The authors thank Miss Kullaporn Chotigkrai, Miss Nannapat Limnoi and Miss Thanathorn Jantharothai for their assistance.

Conflicts of Interest: The authors declare no conflict of interest.

\section{References}

1. Forrest, S.R. The path to ubiquitous and low-cost organic electronic appliances on plastic. Nature 2004, 428, 911-918. [CrossRef] [PubMed]

2. Saleh, N.B.; Milliron, D.J.; Aich, N.; Katz, L.E.; Liljestrand, H.M.; Kirisits, M.J. Importance of doping, dopant distribution, and defects on electronic band structure alteration of metal oxide nanoparticles: Implications for reactive oxygen species. Sci. Total Environ. 2016, 568, 926-932. [CrossRef] [PubMed]

3. Plazas-Tuttle, J.; Das, D.; Sabaraya, I.V.; Saleh, N.B. Harnessing the power of microwaves for inactivating Pseudomonas aeruginosa with nanohybrids. Environ. Sci. Nano 2018, 5, 72-82. [CrossRef]

4. Hashimoto, K.; Irie, H.; Fujishima, A. $\mathrm{TiO}_{2}$ photocatalysis: A historical overview and future prospects. JJAP 2005, 44, 8269.

5. Gaya, U.I.; Abdullah, A.H. Heterogeneous photocatalytic degradation of organic contaminants over titanium dioxide: A review of fundamentals, progress and problems. J. Photochem. Photobiol. C 2008, 9, 1-12. [CrossRef]

6. Kiatkittipong, K.; Assabumrungrat, S. A comparative study of sodium/hydrogen titanate nanotubes/nanoribbons on destruction of recalcitrant compounds and sedimentation. J. Clean. Prod. 2017, 148, 905-914. [CrossRef]

7. Lee, S.L.; Chang, C.-J. Recent developments about conductive polymer based composite photocatalysts. Polymers 2019, 11, 206. [CrossRef]

8. Mukherjee, D.; Barghi, S.; Ray, A.K. Preparation and characterization of the $\mathrm{TiO}_{2}$ immobilized polymeric photocatalyst for degradation of aspirin under UV and solar light. Processes 2014, 2, 12-23. [CrossRef]

9. Zhou, T.-T.; Zhao, F.-H.; Cui, Y.-Q.; Chen, L.-X.; Yan, J.-S.; Wang, X.-X.; Long, Y.-Z. Flexible TiO 2/PVDF/g-C3N4 Nanocomposite with Excellent Light Photocatalytic Performance. Polymers 2020, 12, 55. [CrossRef]

10. Chawengkijwanich, $\mathrm{C}$; Hayata, Y. Development of $\mathrm{TiO}_{2}$ powder-coated food packaging film and its ability to inactivate Escherichia coli in vitro and in actual tests. Int. J. Food Microbiol. 2008, 123, 288-292. [CrossRef]

11. Maneerat, C.; Hayata, Y. Antifungal activity of $\mathrm{TiO}_{2}$ photocatalysis against Penicillium expansum in vitro and in fruit tests. Int. J. Food Microbiol. 2006, 107, 99-103. [CrossRef] [PubMed]

12. Kanazawa, T.; Ohmori, A. Behavior of $\mathrm{TiO}_{2}$ coating formation on PET plate by plasma spraying and evaluation of coating's photocatalytic activity. Surf. Coat. Tech. 2005, 197, 45-50. [CrossRef]

13. Ratova, M.; West, G.; Kelly, P. Optimisation of HiPIMS photocatalytic titania coatings for low temperature deposition. Surf. Coat. Tech. 2014, 250, 7-13. [CrossRef] 
14. Loddo, V.; Marcì, G.; Palmisano, G.; Yurdakal, S.; Brazzoli, M.; Garavaglia, L.; Palmisano, L. Extruded expanded polystyrene sheets coated by $\mathrm{TiO}_{2}$ as new photocatalytic materials for foodstuffs packaging. Appl. Surf. Sci. 2012, 261, 783-788. [CrossRef]

15. Selvin, T.P.; Kuruvilla, J.; Sabu, T. Mechanical properties of titanium dioxide-filled polystyrene microcomposites. Mater. Lett. 2004, 58, 281-289. [CrossRef]

16. Asiaban, S.; Taghinejad, S.F. Investigation of the effect of Titanium Dioxide on optical aspects and physical and mechanical characteristics of ABS Polymer. J. Elastomers Plast. 2010, 42, 267-274. [CrossRef]

17. Sudeepan, J.; Kumar, K.; Barman, T.; Sahoo, P. Tribological behavior of ABS/TiO 2 polymer composite using Taguchi statistical analysis. Mater. Sci. 2014, 5, 41-49. [CrossRef]

18. Skorski, M.R.; Esenther, J.M.; Ahmed, Z.; Miller, A.E.; Hartings, M.R. The chemical, mechanical, and physical properties of 3D printed materials composed of $\mathrm{TiO}_{2}-\mathrm{ABS}$ nanocomposites. Sci. Technol. Adv. Mater. 2016, 17, 89-97. [CrossRef]

19. Sangkatip, R.; Sriseubsai, W.; Kiatkittipong, K. Antibacterial and Mechanical Properties of the $\mathrm{TiO}_{2} / \mathrm{ABS}$ Composites. In Key Engineering Materials; Trans Tech Publications Ltd.: Stafa-Zurich, Switzerland, 2017; pp. 209-213.

20. Fagan, R.; McCormack, D.E.; Dionysiou, D.D.; Pillai, S.C. A review of solar and visible light active $\mathrm{TiO}_{2}$ photocatalysis for treating bacteria, cyanotoxins and contaminants of emerging concern. Mat. Sci. Semicon. Proc. 2016, 42, 2-14. [CrossRef]

21. Ratova, M.; Mills, A. Antibacterial titania-based photocatalytic extruded plastic films. J. Photoch. Photobio. A 2015, 299, 159-165. [CrossRef]

22. Podporska-Carroll, J.; Panaitescu, E.; Quilty, B.; Wang, L.; Menon, L.; Pillai, S.C. Antimicrobial properties of highly efficient photocatalytic $\mathrm{TiO}_{2}$ nanotubes. Appl. Catal. B 2015, 176, 70-75. [CrossRef]

23. Yu, J.; Yu, H.; Cheng, B.; Trapalis, C. Effects of calcination temperature on the microstructures and photocatalytic activity of titanate nanotubes. J. Mol. Catal. A Chem. 2006, 249, 135-142. [CrossRef]

24. An, H.; Zhu, B.; Li, J.; Zhou, J.; Wang, S.; Zhang, S.; Wu, S.; Huang, W. Synthesis and characterization of thermally stable nanotubular $\mathrm{TiO}_{2}$ and its photocatalytic activity. J. Phys. Chem. 2008, 112, 18772-18775. [CrossRef]

25. Zhou, W.; Liu, H.; Wang, J.; Liu, D.; Du, G.; Cui, J. $\mathrm{Ag}_{2} \mathrm{O} / \mathrm{TiO}_{2}$ nanobelts heterostructure with enhanced ultraviolet and visible photocatalytic activity. ACS Appl. Mater. Interfaces 2010, 2, 2385-2392. [CrossRef] [PubMed]

26. Yang, H.G.; Liu, G.; Qiao, S.Z.; Sun, C.H.; Jin, Y.G.; Smith, S.C.; Zou, J.; Cheng, H.M.; Lu, G.Q. Solvothermal synthesis and photoreactivity of anatase $\mathrm{TiO}_{2}$ nanosheets with dominant $\{001\}$ facets. J. Am. Chem. Soc. 2009, 131, 4078-4083. [CrossRef]

27. Rangari, V. Polymer nanocomposite materials for structural applications. In Advances in Nanocomposites-Synthesis, Characterization Industrial Applications; Reddy, D.B., Ed.; IntechOpen: London, UK, 2011; pp. 61-84.

28. Li, H.; Zhang, Z.; Ma, X.; Hu, M.; Wang, X.; Fan, P. Synthesis and characterization of epoxy resin modified with nano-SiO${ }_{2}$ and $\gamma$-glycidoxypropyltrimethoxy silane. Surf. Coat. Technol. 2007, 201, 5269-5272. [CrossRef]

29. Xu, X.; Li, B.; Lu, H.; Zhang, Z.; Wang, H. The interface structure of nano-SiO $2 / \mathrm{PA} 66$ composites and its influence on material's mechanical and thermal properties. Appl. Surf. Sci. 2007, 254, 1456-1462. [CrossRef]

30. Li, X.; Cao, Z.; Zhang, Z.; Dang, H. Surface-modification in situ of nano-SiO 2 and its structure and tribological properties. Appl. Surf. Sci. 2006, 252, 7856-7861. [CrossRef]

31. Pazokifard, S.; Mirabedini, S.; Esfandeh, M.; Mohseni, M.; Ranjbar, Z. Silane grafting of $\mathrm{TiO}_{2}$ nanoparticles: Dispersibility and photoactivity in aqueous solutions. Surf. Interface Anal. 2012, 44, 41-47. [CrossRef]

(C) 2020 by the authors. Licensee MDPI, Basel, Switzerland. This article is an open access article distributed under the terms and conditions of the Creative Commons Attribution (CC BY) license (http://creativecommons.org/licenses/by/4.0/). 